\title{
TRANSMEDIA PEDAGOGICAL MATERIAL FOR SPANISH TEACHING IN BRAZIL: VOICES FROM LATIN AMERICAN PERIPHERIES
}

\author{
MATERIAL PEDAGÓGICO TRANSMÍDIA \\ PARA O ENSINO DE ESPANHOL NO BRASIL: \\ VOZES LATINO-AMERICANAS PERIFÉRICAS.
}

\author{
Rogério Tilio* \\ Valdiney Costa Lobo *
}

\begin{abstract}
This article aims to present the results of a research involving Spanish classes at COLUNI/ UFF. The investigation about multimodal literacies (KALANTIZS; COPE, 2012) focuses on the production of resistance/reexistance transmedia pedagogical materials. In a first moment, bilingual (Portuguese/Spanish) comic strips are produced, aiming at the problematization of ethnical and racial issues. In a subsequent moment, secondary narrations about the theme are produced: raps and animations. The investigation results are expected to enlighten pedagogical practices with the material in high school classes, aiming at developing students' critical literacy.
\end{abstract}

Keywords: transmedia pedagogical material, critical literacy; Spanish teaching.

\section{RESUMO}

Este artigo tem como objetivo apresentar os resultados de uma pesquisa envolvendo aulas de espanhol no COLUNI/UFF. A pesquisa sobre letramento multimodal (KALANTIZS, COPE, 2012) concentra-se na produção de materiais pedagógicos transmídias de resistência/ reexistência. No início, as personagens e os quadrinhos são produzidos com o objetivo de problematizar preconceitos raciais e xenófobos. Em um momento posterior, os personagens e as tiras em quadrinhos perpassam e entrecruzam-se com as narrativas de outros textos, a fim de possibilitar práticas de letramentos de leitura e escrita em espanhol. Espera-se que a produção do material pedagógico transmídia possa desenvolver a reflexão e a criticidade nos alunos.

Palavras-chave: material pedagógico transmídia; letramento crítico; ensino de espanhol.

\footnotetext{
* Universidade Federal do Rio de Janeiro, UFRJ, Rio de Janeiro, RJ, Brasil. rogeriotilio@letras.ufrj.br Orcid: https://orcid.org/0000-0002-3635-9395

** Universidade Federal da Integração Latino-americana, UNILA, Foz do Iguaçi, PR, Brasil. valdineylobo@gmail.com Orcid: https://orcid.org/0000-0003-0341-907X
} 


\section{INTRODUCTION}

Our objective with this article is to present an ongoing research proposal carried out by a junior research scientific project involving Spanish classes at Colégio Universitário Geraldo Reis - COLUNI/UFF which is coordinated by one of the authors of this article and two other students enrolled in the school. The investigation on multimodal literacies (KALANTIZS, COPE, 2012) focuses on the development of resistence/reexistence (SOUZA, 2011) transmedia pedagogical materials in Spanish. Within a transmedia perspective, there is usually a primary narrative and some other secondary ones. As a result, the main narrative will be developed in the discursive genre (BAKHTIN, [1952/1979] 1997) comic strips, each telling an independent story.

The first phase of the material development concerned the production of the characters. The idea was to create some characters who could problematize contemporary Latin-American cultures and identities as a way to give voice to the ones who are marginalized and socially excluded. During the second phase, the group created the comic strips as secondary narratives in the characters' identity construction.

The third phase is about the ownership of the transmedia production so as to elaborate a proposal for a reexistence transmedia pedadogical material designed for a third-year-high school group at COLUNI-UFF. The material was designed with the purpose of empowering students besides contributing to their critical thinking regarding the society they live in.

The activities created for the material are anchored in the Bakhtin Circle language perspectives ([1929] 2004) as well as Halliday's (1994). We have also considered the categorization proposed by TILIO (2013) and TILIO \& Rocha (2009) which articulates a dialog between the elements that constitute Bakhtin's discursive genres and Halliday's metafunctions, also known as dimensions of language. Furthermore the notions of critical reading (BRASIL, 1998) and critical literacies (BRASIL, 2006) towards the elaboration of dialogic and responsive (VOLÓCHINOV, [1929] 2017) proposals in the classroom have been essential to the project.

\section{TRANSMEDIA LITERACIES}

Throughout this section we will discuss and problematize the concept of transmedia literacies in teaching additional languages. It is important to cross- 
reference theories on literacies (KALANTIZS; COPE, 2012) and transmedia (JENKINS, 2008) to resignify contemporary transmedia literacies.

Pior to presenting our own understanding of practices of transmedia literacies, it is fundamental to refer to the notion of multiliteracies developed by the New London Group (THE NEW LONDON GROUP, 1996). They advocate that there are two types of multiplicities in the meaning-making process which the prefix multireinforces: the multiplicity of cultural background that an individual must have to act and take a stand in the contemporary globalized world, and the multiplicity of ways to convey meaning (multimodality) present in our highy semiotisized contemporary society. The first type is centered on social diversity, in contexts and domains where a variety of discursive genres (BAKHTIN, [1952/1979] 1997) circulate, whereas the latter alludes to multimodality, i.e., to the ways of conveying meaning through oral, visual, audio, gestural, tactile, and spatial patterns. In this article, we agree with the terminology "literacies"; however without the prefix multi-, and we use "literacies" instead of "literacy" just like Kalazantizs \& Cope (2012) use - who were authors of the New London Group that no longer exists. As to the ideas conveyed by the term "literacies", the authors stress that its use in the plural comprehends the practices of multimodal-semiotic literacies (languages) - an idea aligned with the ones that their Group had mentioned. Therefore, by understanding that contemporary literacies encompass semiotic multiplicities, we embrace the terminology "literacies" that Kalantizs \& Cope (2012) provide.

Such authors give emphasis to the fact that "literacies", according to the meaning provided, enable social participation and promote engaging experiences to those who come from different cultural, social and economic contexts. The authors propose an agenda that contemplate three pillars: professional training, civic-economic participation, and social equity. The first is about an individual living and being able to express himself/herself and having access to available cultural resources. The second includes the work communicative capabilities, the engagement in political processes and the participation in the community. The third proposes access to education as a way to access social and material resources.

The three elements mentioned are central to rethink contemporary literacies. In current societies, it is important that individuals become familiar with these 3 pillars in order to resignify their fragmented and fluid identities (HALL, [1992] 2006). It is through several social interactions in our everyday life that engaging taking place. Such interactions are established through media literacies, especially due to the emergence of digital technologies, in which we can see contemporary transmedia practices (JENKINS, 2008). Transmedia narratives which are primarily 
used for communication point to a central story being told within a certain discursive genre. Subsequently-at times simultaneously - secondary narratives are carried out in other genres, i.e., a main story can be originated from a comic strip and a secondary from webseries, animations, or games, for example.

The most important aspect in a transmedia proposal is the elaboration of a consistent primary narrative. In addition, the use of other genres enables the interlocutor to reconstruct secondary stories based on the characters from the primary. The use of other genres is meant to have the interlocutor adapt the primary narrative instead of transporting it to the other genres in question.

The practices of literacies based on transmedia narratives enable the individual to express himself/herself and take a stand in the world which carries individual and social relevance since they take place in a participatory culture (JENKINS, 2008) in which fans interact with productions.

The term 'fan' is quite used in such narratives due to the fact that stories are generally developed by companies that invest millions. Harry Potter and Star Wars are examples of such narratives and in them we can find a primary narrative (a literary one, regarding Harry Potter, and a cinematographic one regarding Star Wars) along with secondary narratives told by several other visual-verbal genres. Many narratives have fan communities that interact, debate and recreate the situational contexts of the narratives; hence acting in a responsive and dialogic way (VOLÓCHINOV, [1929] 2017). Moreover, by creating meaning from the socio-cultural contexts found in the transmedia narratives, the individuals are able to resignify their identities through encounters with alterities (SILVA, 2000).

In regard to the civic-economic participation, the transmedia literacies encourage their fans to commit to virtual and presential communities. As to the virtual ones, collaborative construction of new paths and developments to the characters' stories contributes to the stimulation of creativity besides being an opportunity to think critically and take a stand in the world, considering the situational contexts of the narratives. In presential communities, individuals have a space to rethink their roles in society which is enabled by the discursive conflicts they might have with other fans in face-to-face encounters, such as events and meetings. Additionally, many discussions concerning the themes found in the narratives are present in formal environment such as school and the workplace.

With reference to the third pillar, which is social equity and whose goal is to provide access to education, transmedia literacies can play relevant roles. The first we outline is centered in the construction of a school environment where multimodal genres are used, especially the one that contributes to an understanding 
of transmedia narratives. Consequently, it is possible to approach a participative culture at school as students take part in the meaning-making processes from the stories told, mainly the secondary narratives. Furthermore, transmedia literacies provide the means to collaborative work in the classroom seeing that students need to resignify the narratives and, therefore, they contribute with their own viewpoints to the characters' paths. This approach thus contributes to social equity since many students have access to this practice at school.

Throughout this first section we sought to align practices of contemporary literacies with the perspectives of transmedia narratives. To achieve that, we embraced three principles proposed by Kalantzis \& Cope (2012) and we understand that transmedia narratives are present in personal training, civic-economic participation and social equity. Taking into account that it is important that individuals make sense from transmedia literacies in contemporaneity, it is crucial that the contemporary school, as a formal educational institution, contemplate the transmedia literacies. In our next section, we will present a pedagogical proposal based on the production of transmedia pedagogical materials for Spanish teaching.

\section{TRANSMEDIA PEDAGOGICAL MATERIALS}

In order to develop pedagogical materials to teach Spanish in a contemporary context of a public school, we have aligned the importance of transmedia narratives (JENKINS, 2009) with the proposal for literacies (Kalantzis \& Cope (2012), as we have mentioned earlier, and we have also articulated them with Rojo (2009, 2012), Fabrício (2006), Silva (2000) and Souza (2011).

The production of transmedia materials is related to convergence culture (JENKINS, 2009). The author outlines that platforms converge to disseminate several products and this is done through multiple semioses, i.e., contents are announced through several discursive genres and they originate a product. Thus, it is important that the students interact in participatory culture, making comments about the narratives and their characters and such practice can contribute to the development of critical and reflexive attitudes. Jenkins (2009) points to the fact that creating stories from transmedia products enables the development of a collective intelligence - according to the author, it usually happens in fan community.

Jenkins (2009) stresses that each transmedia narrative (or episode of a transmedia narrative) must be independent but it should also contribute to a better understanding of the big picture, which are the other stories that constitute the plot. He also points out that transmedia narratives demand a highly structured 
coordination. Considering the perspective we have presented, the product must involve multimodal genres that are intertwined and which result from a primary narrative and other secondary ones. Therefore, we propose that the production of transmedia pedagogical materials envision the possibility of:

- Seeing Spanish classes as an emergent space for the actors' multiple voices (BOHN, 2013) in the teaching-learning process;

- Promoting debates on ssentialized and crystalized identities FABRÍCIO, 2006) based on universal truths;

- Giving voice to the outcasts and arginalized (MOITA LOPES, 2006) from the Latin American peripheries KLEIMAN, 2013);

- Validating reexistence literacies (SOUZA, 2011) such as hip hop, graffiti etc. in institutions of formal education;

- Providing the means towards critical reading (BRASIL, 1998) and critical literacies (BRASIL, 2006) in Spanish, as an additional language;

- Contributing to students' critical and reflexive development through problematizations anchored to social discourses which give voice to individuals in peripheries;

- Developing transmedia narratives (JENKINS, 2009) by articulating discursive genres with multiple semioses;

Although the transmedia narrative has its start with the big marketing corporations and the entertainment companies, our idea for this article is to present the prototype $(\mathrm{ROJO}, 2013)$ of a pedagogical material whose objective is to resignify the teaching of Spanish. We will do so by focusing on our objectives and by understanding that the classroom should be open to multiple discourses (VOLÓCHINOV, [1929] 2017) and to students' attitudes. In addition, it should be a heterogeneous space constructed socially.

Bohn (2013) mentions how important it is to avoid normalizations in teaching languages and he believes that in education the self-representation of the inferiors rarely takes place. With that in mind and regarding the context of the public schools, it is important to empower students so that their voices are present in their interactions with the transmedia material. Besides, in a collaborative perspective, students can also take part in the production of the narratives development and, consequently, in their own material. The multiplicity of voices is seen since the beginning of the project and it is articulated with the teacher's voice. Therefore, it is fundamental that the students take part in the transmedia construction as to give voice to their multiple identities (MOITA LOPES, 2003). 
As an attempt to give voice to multiple heterogeneous voices, Fabrício (2006) proposes the concept of 'unlearning' in order to resignify the way we look at the world, by deconstructing Eurocentric paradigms that are essentialized. The author stresses the urge to dehistoricize the object, i.e., not to focus on how it was created or under which regimes of truth and their historical and social circumstances. By doing that, it is possible to find new meaning in other models of society and make space to marginalized voices that are socially excluded: the voices of the South (MOITA LOPES, 2006).

When it comes to giving voice to the marginalized, considering context of the Spanish language, it is important give visibility to the individuals in the Latin American peripheries (KLEIMAN, 2013). The concept of periphery in this article does not simply comprehend the socio-economic aspect, but it also includes social, cultural and identity ones. Thus, it is important to contemplate the marginalized identities who do not fit into the essentialized-middle class-homogeneous-white profile (especially in terms of Spanish teaching in which there is a tendency to prefer the Eurocentric perspective, the so called "Spanish from Spain"). Our proposal here is to empower the identities who transcend the norm (SILVA, 2000), and to give them visibility through the development of transmedia narratives.

An endeavor to naturalize several peripheral identities is the development of transmedia narratives whose marginalized characters and themes take place in emergent stories of the non-place (FABRÍCIO, 2006). In order to do that, it is possible to resort to literacies of reexistence (SOUZA, 2011), i.e., those that emerge from peripheral places and contemplate marginal voices such as the hip hop, the rap, the graffiti and others.

As an attempt to validate these marginalized identities, we can relate the production of transmedia narratives to anti-hegemonic stories through several discursive genres that embrace multiple literacies. In the prototype we will present, the primary narrative consists of comic strips whereas the secondary narratives consist of hip hop and animations.

We chose the comic strips for the second narrative since they enable the construction of a reflexive and critical perspective towards contemporary issues. Furthermore, the comic strips are humorous, short and allow the reader to infer facts about the stories and their characters. In our transmedia approach, the group designed strips that would problematize the cultural identities in Latin America in order to give voice to the marginalized Latin Americans, and revisit discussions on racial/ethnic issues, consumption and xenophobia. 
Rojo (2012) highlights the importance of critical and protagonist literacies in the teaching-learning process. Even the Brazilian Ministry of Education (BRASIL, 2006) has made references to the importance of critical literacy (CERVETTI et $\mathrm{al}, 2001)$ in teaching additional languages. The organ states that critical literacy is related to representations and social constructions by exploring what is not said and by analyzing the linguistic-discursive choices made (what was chosen contrasting to what could have been but wasn't) and who wins and loses depending on these choices (BRASIL, 2006).

The purpose of having critical literacy practices is to lead students to understand the social and historical contexts in which texts are created, distributed and how they circulate. This should be done taking into consideration the relations of power that are involved. Thus, the elaboration of transmedia narratives designed for Spanish classes aims at problematizing marginalized identities in several Latin American contexts, contributing to the contemplation of new and multiple perspectives.

It is important to mention that the research group carrying the junior research scientific project described in this article designs the narratives based on comic strips, animations and rap so as to develop a transmedia product. The production phase consists of discussions, creation and interactions involving the members of the group: two students who receive funding and a professor who supervises.

Since the material that will be distributed is a prototype, the students from COLUNI-UFF will be the first to receive it, more specifically the ones from class 3001. According to the lesson plan prepared for the class, the theme on AfroLatin American minorities will be discussed. As previously mentioned, for the transmedia project, the first narrative will be developed from two characters. Later, we will propose the elaboration of verb-visual narratives through the elaboration of reflective and critical comic strips. To carry out this project, it is essential to see the school as a space for knowledge production that integrates the use of new technologies to the teaching-learning process of additional languages.

The transmedia narrative produced by the group has the objective to rethink the production, reception and design phases and it encourages other students to interact with the story so that they can contribute to the narrating process. Consequently, production and reception happen in a responsive and dialogic way (VOLÓCHINOV, [1929] 2017). The design also facilitates the interaction with students and it enables them to resignify the illustrations produced in the transmedia discursive genres, which means that other students can also create other stories through the use of comic strips, hip hop, animations and other genres. 
Therefore, the ethics in transmedia production is intertwined with its own reception and production of other stories. Additionally, the proposal for new ethics (ROJO, 2012) also presupposes a perspective towards critical literacy. Rojo (2012) points to the elaboration of new ethics and strategies that are not so based on copyright laws but on interaction, "whether on reception, production or design" (ROJO, 2012, p.6). The author stresses how important it is to appreciate individuals aesthetic value even if they are different from what people are accustomed to; such exercise leads to new knowledge and perspectives.

With regard to aesthetics, the proposal for transmedia narratives allows the interaction of several discursive genres with one another through the primary and secondary stories. To this end, it is imperative to observe the resignifications in each and every genre. Interlaced aesthetics can contribute to students' curiosity and their pursuit of information on the characters in multiple literacies, which is fundamental to the negotiation of meanings during the interaction with the transmedia production genres.

In an effort to contribute to the connection between transmedia production in Spanish classes and the process of giving voice to social minorities, we focus on transmedia reexistence genres. As the production originated in the context of a public school, we can say that the stories emerge from the periphery, which means that their authors are part of this context of social marginalization.

To develop activities for the transmedia narratives we resort to TILIO (2013) and TILIO \& Rocha (2009) who establish a connection between the features of Bakhtin's discursive genres ([1952/1979] 1997) and Halliday's metafunctions (HALLIDAY \& HASAN, 1989; HALLIDAY \& MATTHIESSEN, 2014) and explain what the authors call 'dimensions of language'(TILIO, 2013; TILIO; ROCHA, 2009).

\section{THE ELABORATION OF ACTIVITIES THAT CONTEMPLATE THE DIFFERENT DIMENSIONS OF LANGUAGE}

According to Bakhtin ([1952/1979] 1997), the discursive genres are relatively stable types of enunciations that can be done orally or in written forms besides being a way of acting socially. To Bakhtin ([1952/1979] 1997), discursive genres have three basic features that are related to the enunciation in its totality: the theme, the style and the compositional form; these elements are 'marked by the particularities of a sphere of communication' ([1952/1979] 1997, p. 279). 
The theme can be understood as the subject of the enunciation (what it is about) - it is a content affected by ideologies which is accomplished through the genres. The compositional form concerns the elements of the discursive and semiotic structures that make a text belong to a certain genre. Finally, the style regards the individual and generic issues of selection such as syntactic and lexical choices. It is important to mention that these elements are not autonomous; they are directly linked to one another, interdependent and inextricable in a dialogicdiscursive process.

To develop the activities, we embraced the categorization suggested by Tilio \& Rocha (2009) and Tilio (2013): ideational-thematic, interpersonal-compositional and textual-stylistic. Such categorization is based on the principle that the language is multidimensional as three types of meaning are realized simultaneously - the ideational, the interpersonal and the textual (HALLIDAY; HASSAN, 1989; HALLIDAY; MATTHIESSEN, 2014). The ideational refers to the representation and construction of reality by the reproduction or validation of knowledge and beliefs; the interpersonal establishes relationships between the text participants based on identities and social relations; the textual materializes the text since the way the information is distributed indicates the way the ideas are developed. When these meanings are materialized in the discourse, the embrace the generic features we have mentioned previously.

Anchored in the theories presented by Bakhtin ([1952/1979] 1997) and Halliday (HALLIDAY; HASSAN, 1989; HALLIDAY; MATTHIESSEN, 2014), TILIO \& Rocha (2009) and TILIO (2013) provide a categorization for the dimensions of language that was used in the development of the activities which is the object of this article. The objective of the ideational-thematic dimension is to elaborate activities that problematize the social and cultural contexts of the transmedia production by providing a new perspective to students' realities and experiences. The proposals might lead to debates on identities that will activate their knowledge of the world and of their own backgrounds (BRASIL, 1998) through the representation of the characters. In this dimension it is essential to observe what is being represented.

The interpersonal-compositional dimension tackles interpersonal relationships and, thus, the activities focus on observing identity relations and power relations not only among the characters of the transmedia narratives but also among the narratives and the students and the teacher. Therefore, the space where it happens is a space to be critical and reflexive. We highlight that the activities carried out in class should make room for heterogeneous voices (TILIO, 2013) and 
reject the idea that the teacher only reproduces or validates the discourse present in the material. Consequently, the activities in the transmedia proposal should appreciate the discursive multiplicity and start debates that stimulate reflections.

The activities can contribute in a bigger or smaller scale to the identity issues in the transmedia material. For that reason, it is important, in this dimension, to negotiate the multiple voices - the students', the teacher's, the material's (which are present in the characters' mouths, in other non-linguistic semioses and in the conditions of production) - and avoid monosemic homogeneous discourses. The issues are to be oriented towards the multiplicity of discourses present in the text and to the power relations positionings seen in several genres. In this dimension it is relevant to know who is being represented and constructed; these choices as well as their reasons should be problematized.

As to the textual-stylistic dimension, the activities should focus on the development of issues regarding the verbal and non-verbal materializations whether they are found in transmedia genres or in the directions for the activities. The idea here is to discuss how the lexicogrammatical choices of the transmedia genres contribute to the meaning-making process. It is important to notice that the grammatical discourse is relevant to the negotiation of meanings between the interlocutors. The studies of this dimension seek to understand how the linguistic materialization contributes to the construction of the other dimensions.

The following section describes the protype (ROJO, 2013) of a transmedia pedagogical material for the teaching of Spanish that we propose.

\section{THE PROTOTYPE}

The prototype consists of a draft of the reexistence transmedia material sequence for Spanish classes aiming at the problematization of the marginalized identities in Latin America. While assembling this material, we sought to align the aforementioned theoretical foundations with the development of the discursive genres and the elaboration of activities. The transmedia prototype develops from three points: the elaboration of two main characters (Fulano and La Boliviana), the production of comic strips, and the construction of activities for teaching Spanish.

In the prototype, the characters and comics are related to other multimodal texts, because the transmedia material we present aims to produce meanings through fictional and real narratives, producing multiple meanings. The production seeks to give voice to the marginalized in Latin America, therefore, our goal is to 
develop a reexistence transmedia pedagogical material. Below is the production prototype:

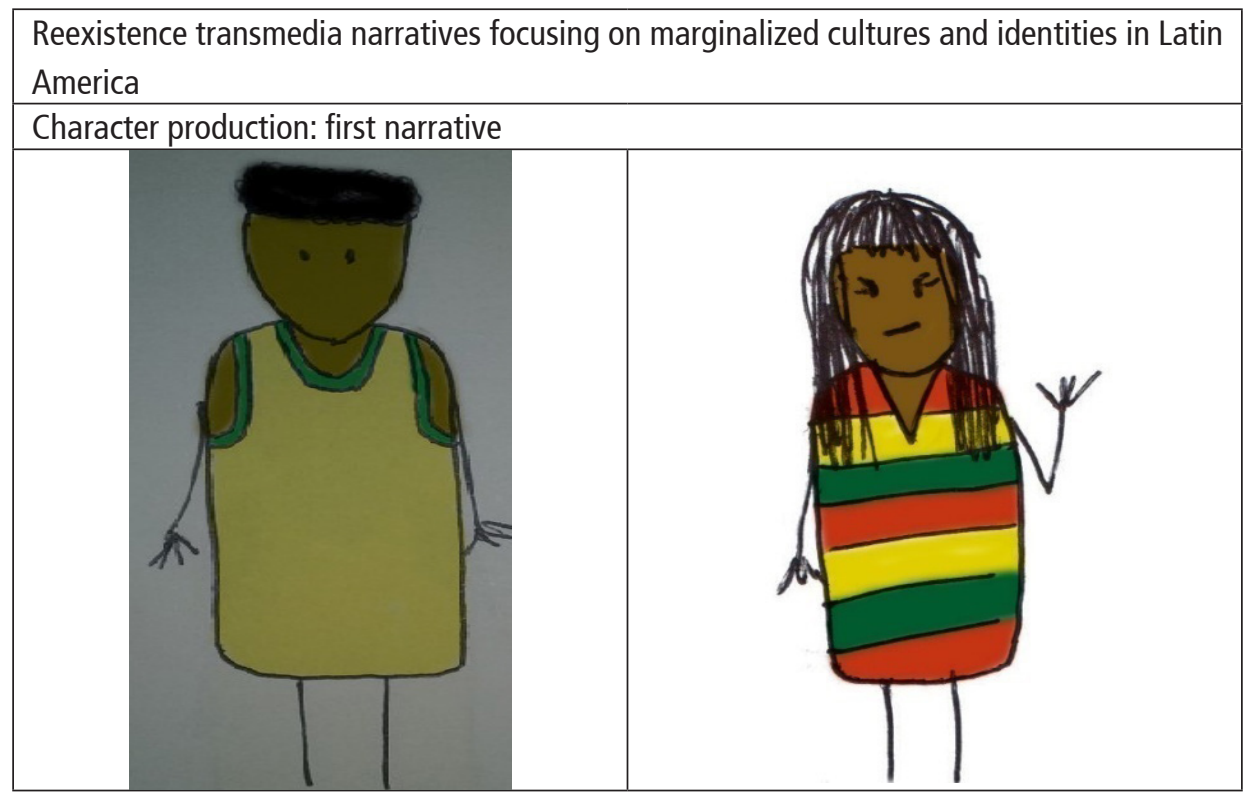

The construction of Fulano with the yellow shirt, alluding to that of the Brazilian team, has two reasons: the first one is to contribute to the deconstruction of a negative cliché, from a positive one, which aims to produce body-discursive positions of reexistence with the construction of a black boy and student of public school; the second seeks to problematize the social identities of black teenagers built in comics that refer to soccer players: Neymar, Pelezinho and Ronaldinho Gaúcho, all from Turma da Mônica, as if this were the only possible identity for black teenage characters (wearing a shirt referring to the Brazilian team and be a soccer player).

La Boliviana character was built through a closer look at the new migratory flows of Bolivians to the metropolises of Rio de Janeiro and, especially, São Paulo. It seeks to reestablish some identity constructions of Bolivian immigrants in Brazil, especially in transglobal cities such as São Paulo and Rio de Janeiro. She is a teenager and daughter of Bolivian immigrants who immigrated to Brazil to work in clothing factories in São Paulo. 


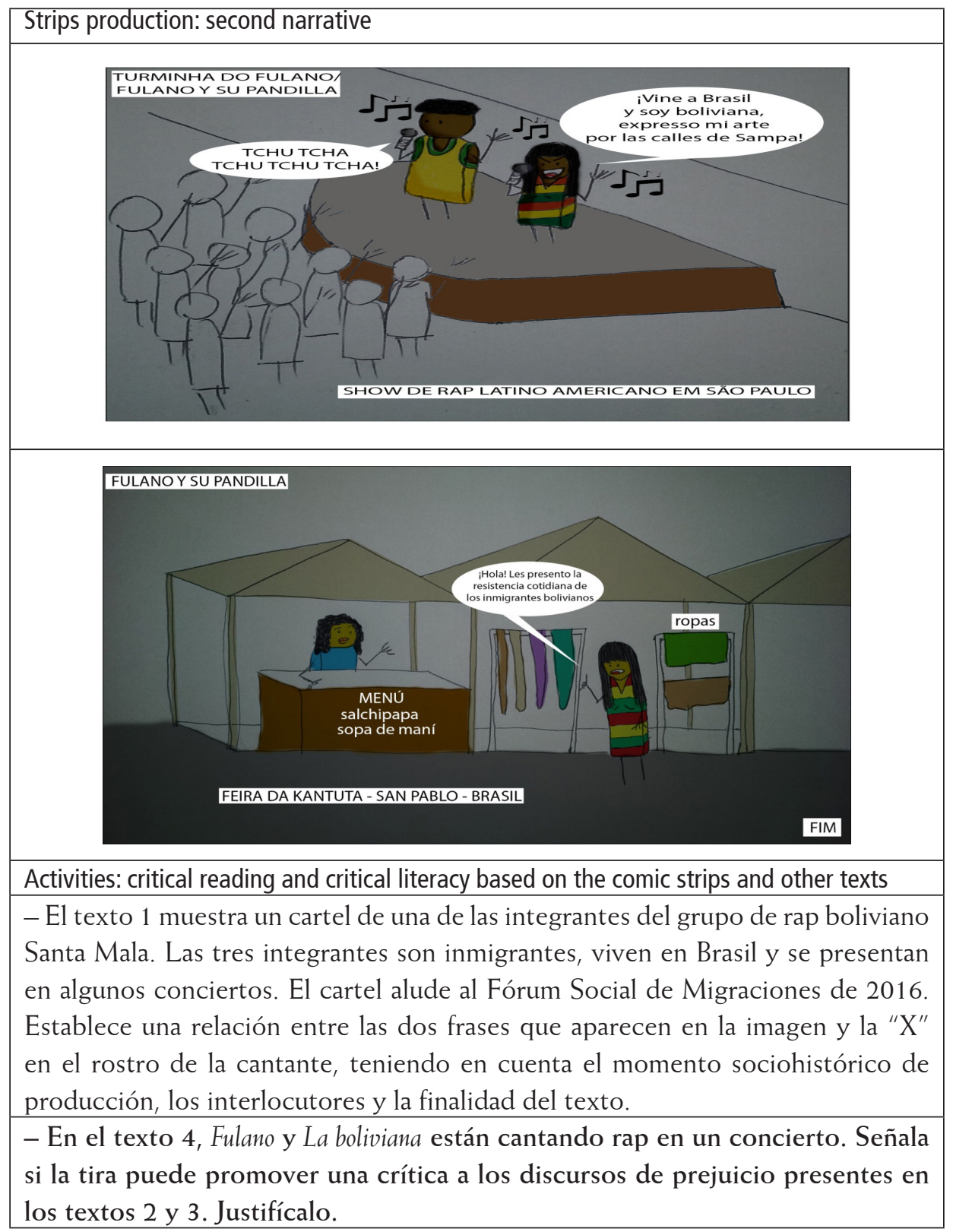




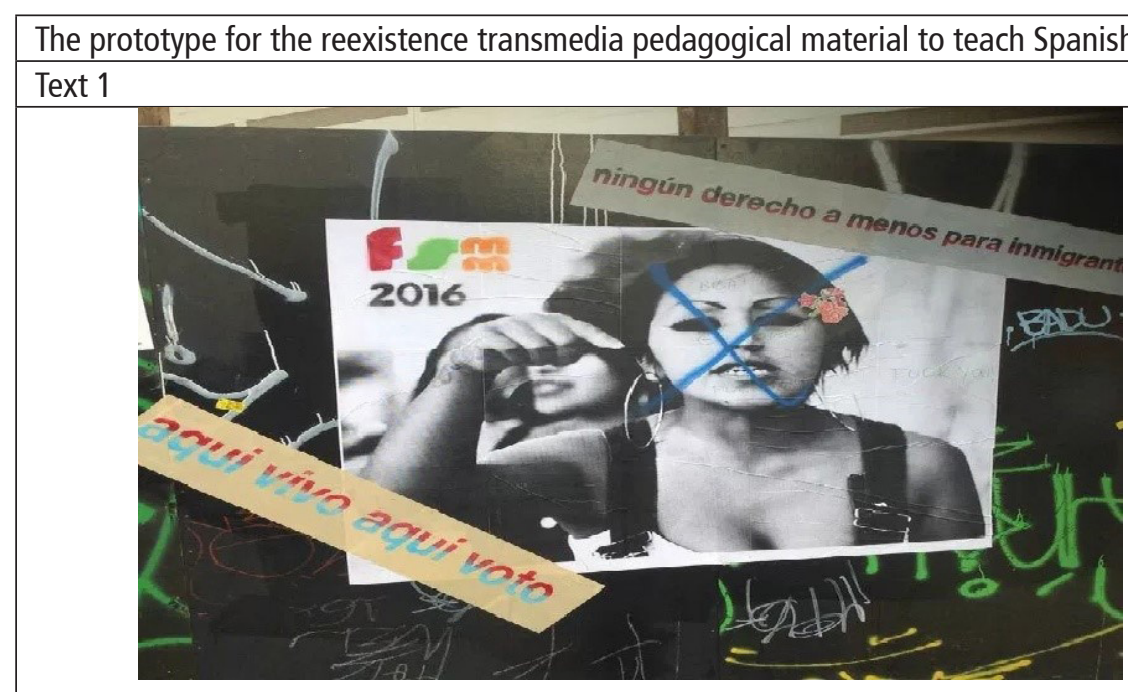

Available at: http://www.zonasuburbana.com.br/sao-paulo-a-xenofobia-e-seu-exemplocotidiano/. Access on 17/11/2017.

El texto 1 muestra un cartel de una de las integrantes del grupo de rap boliviano Santa Mala. Las tres integrantes son inmigrantes, viven en Brasil y se presentan en algunos conciertos. El cartel alude al Fórum Social de Migraciones de 2016. Establece una relación entre las dos frases que aparecen en la imagen y la " $\mathrm{X}$ " en el rostro de la cantante, teniendo en cuenta el momento sociohistórico de producción, los interlocutores y la finalidad del texto.

\section{Text 2}

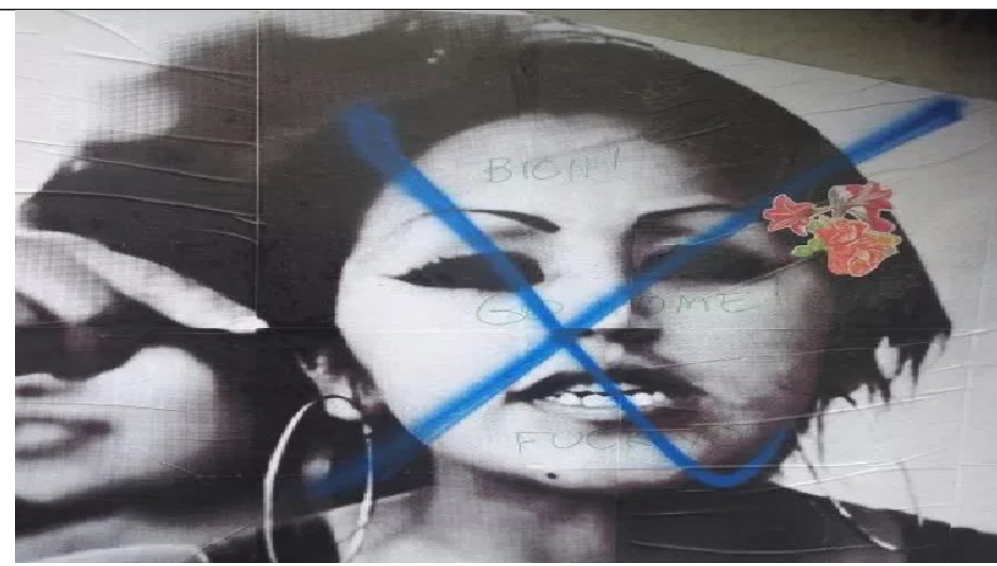

Available at: http://www.zonasuburbana.com.br/sao-paulo-a-xenofobia-e-seu-exemplocotidiano/. Access on 17/11/2017. 


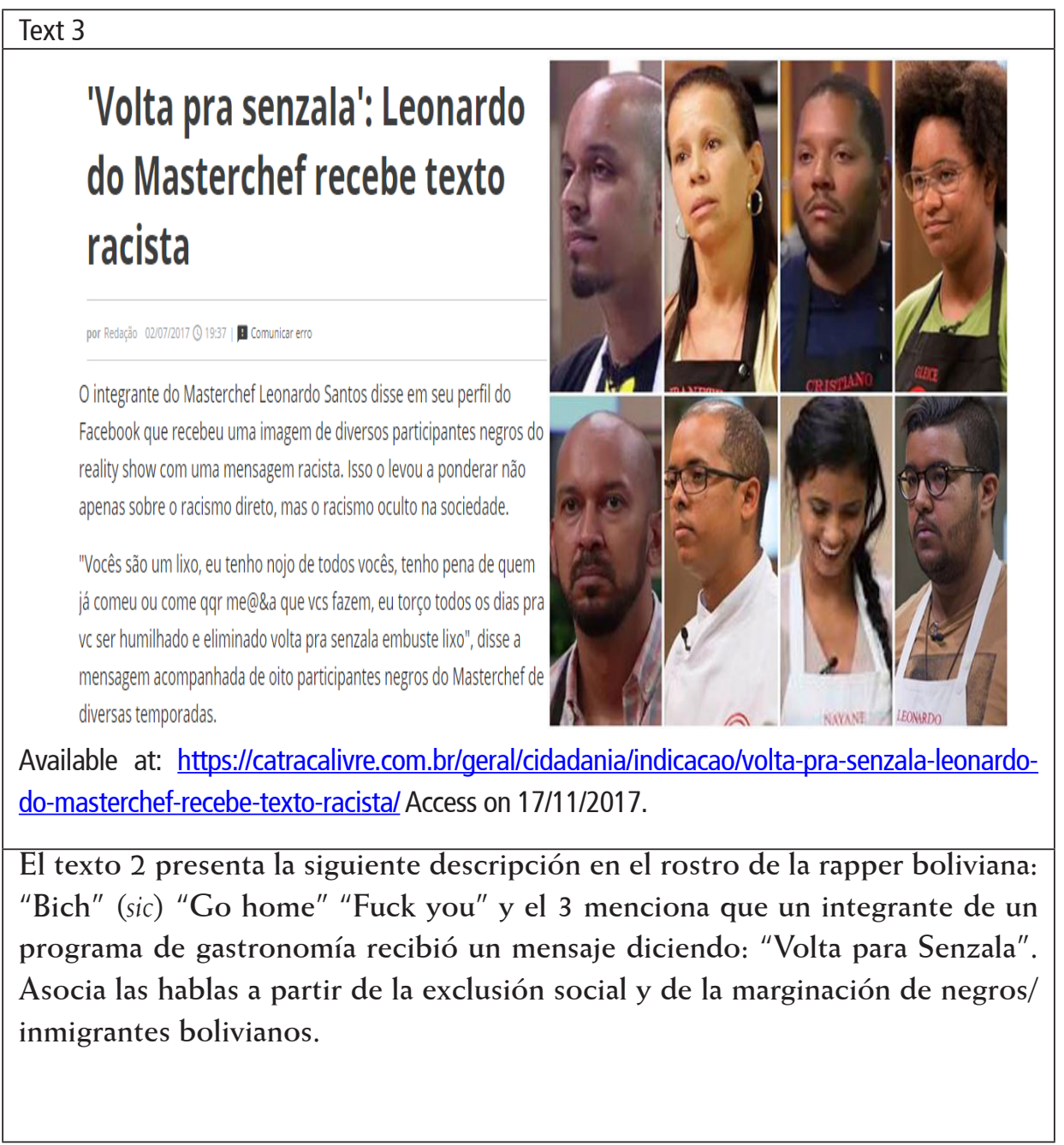




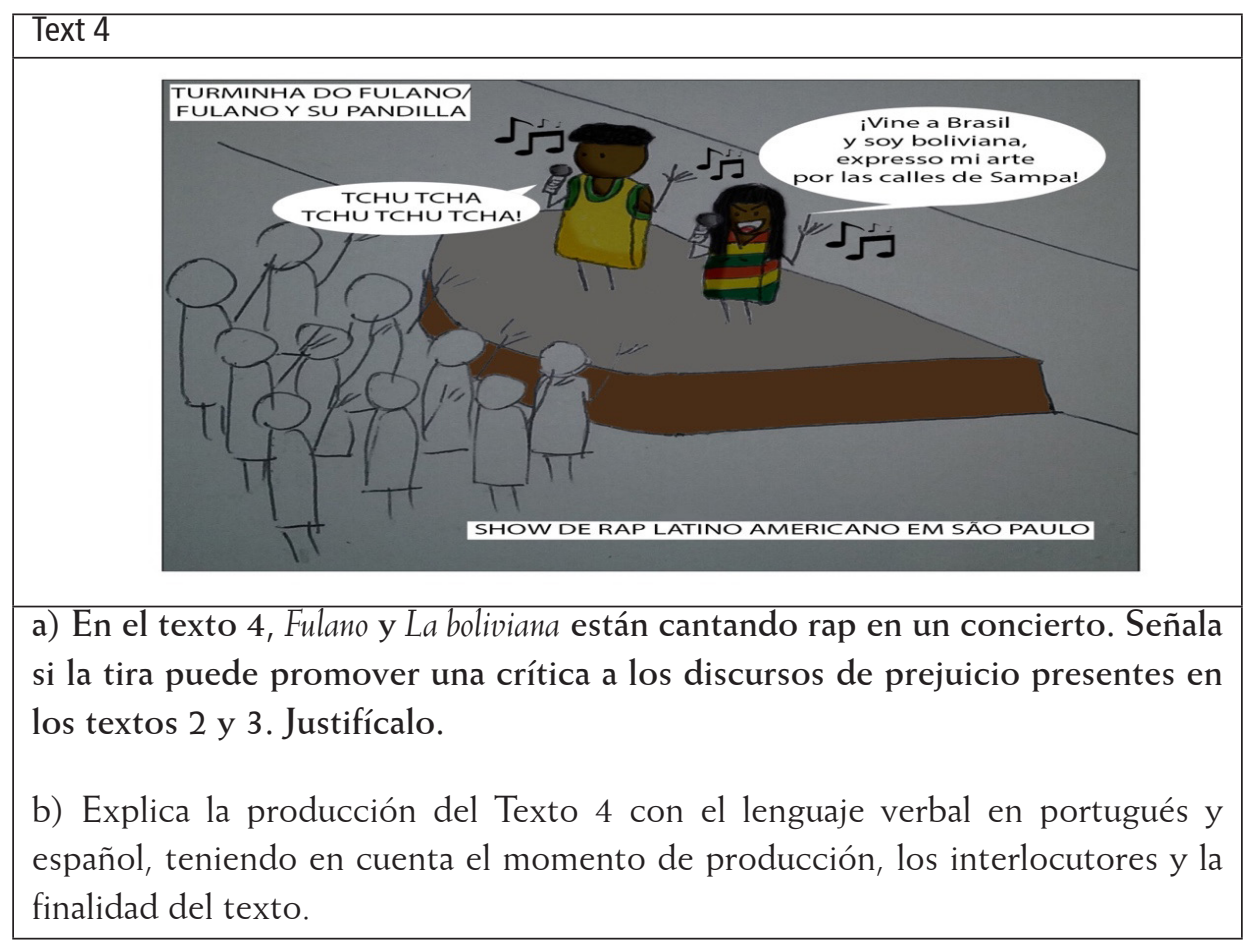




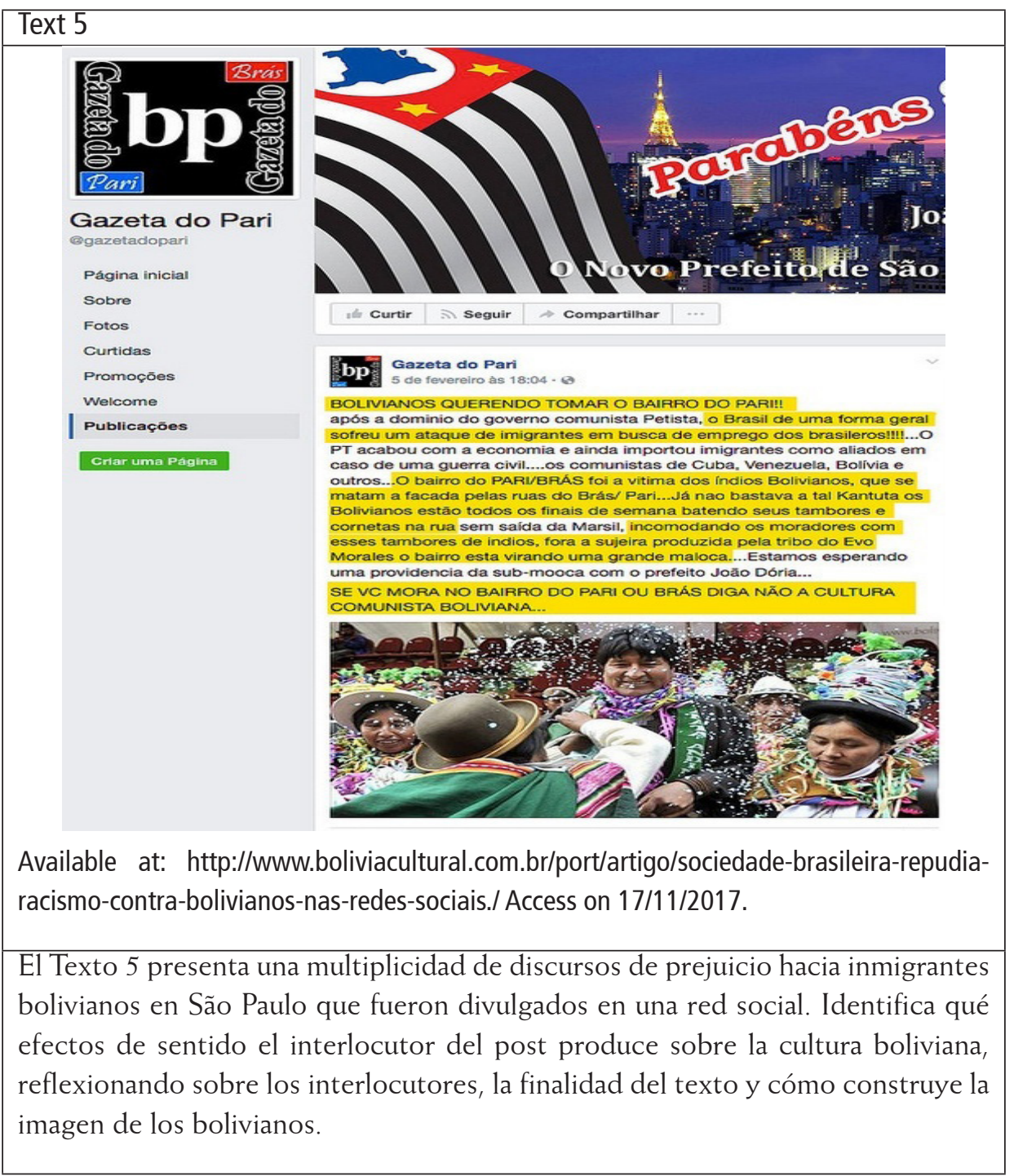




\begin{tabular}{|l|l|}
\hline Text 6 \\
\hline FULANOY SU PANDILLA \\
FElRA DA KANTUTA-SAN PABLO-BRASIL \\
salchipapa \\
sopa demani
\end{tabular}

According to the prototype above, there is a strict relation between the development of the material and the activities for critical reading and critical literacy. In the first part, the secondary narratives must complement the primary. Thus, it is important to develop stories based on the characters' identity construction in order to establish a link between them. In addition, the voices of minorities must be present as a way of resisting the essentialized-homogenous identities and cultures.

In terms of elaborated activities, the language dimensions (TILIO, 2013) are present in the development of critical reading and critical literacy practices. The interactions in the classroom should contribute to multiplicity of voices mixed - the students', the teacher's and the material's - through critical attitudes towards the 
pursuit of heterogeneous classroom. Besides stimulating the students to take part in a participatory culture, the activities on the primary and secondary narratives help the students envision the development of pedagogical material in it totality.

An example of an early prototype, with some genres and activities to be carried out, can be found in the Appendix. It is essential to point out that we do not intend for this proposal to become restricted for it would go against the principles in this prototype which assures that other people can suggest different ways to work with it.

\section{FINAL REMARKS}

In this article we have sought to present the prototype of a reexistence transmedia pedagogical material to teach Spanish as a way to promote reflection on the identity issues of contemporary minorities in Latin America. As a result, in the proposal we presented, the discursive genres try to encompass marginalized identities from the perspective of afro-descents and Spanish speaking immigrants in Brazil.

We should mention that the debates on the elaboration of each genre found in the material were conducted by the research group; therefore everyone participated in the creation of the scripts and in the physical and psychological description of the characters. This factor was fundamental for the project so that the students (who received funding to participate in project) who could understand the social, cultural and educational relevance of the transmedia project. Although the research professor, who was also the coordinator of the project, was the one to think about a moment to develop activities, there was always a debate with the group about the planned activities.

At last, we hope that by using the reexistence transmedia material in the Spanish classes individuals can resignify Latin American identities. To achieve that, the multiple voices of students at the public school COLUNI-UFF should be appreciated since many of them live in peripheral and socially marginalized contexts.

\section{REFERENCES}

BAKHTIN, M. [(1952) 1979]. Os gêneros do discurso. In: Estética da criação verbal. 2. ed. Rio de Janeiro: Martins Fontes, 1997. 
BOHN, H. Ensino e aprendizagem de línguas: os atores da sala de aula e a necessidade de rupturas. In: MOITA LOPES, L. P. (Org.) Linguística Aplicada na modernidade recente: festschrift para Antonieta Celani. São Paulo: Parábola, 2013.

BRASIL. Secretaria de Educação Fundamental. Parâmetros curriculares nacionais: terceiro e quarto ciclos do ensino fundamental: língua estrangeira. Brasília: MEC/SEF, 1998.

BRASIL. Orientações Curriculares para o Ensino Médio. Vol 1. Brasilia: Ministério da Educação, Secretaria de Educação Básica, 2006.

CERVETTI, G.; PARDALES, M.; DAMICO, J. A tale of differences: comparing the traditions, perspectives and educational goals of critical reading and critical literacy. Reading Online, v. 4, n. 9, 2001. Available at: https://eric.ed.gov/?id=EJ662487. Access on 13/04/2017.

FABRÍCIO, B. Linguística aplicada como espaço de "desaprendizagem": redescrições em curso. In: MOITA LOPES, L. P. (Org.) Por uma Linguística Aplicada INdisciplinar. São Paulo: Parábola, 2006.

HALL, S. [1992] A identidade cultural na pós-modernidade. 11. ed. Rio de janeiro: DP\&A, 2006.

HALLIDAY, M. An introduction to Functional Grammar. 2. ed. London: Arnold, 1994.

HALLIDAY, M.; HASAN, R. Language, context and text: aspects of language in a socialsemiotic perspective. 2. ed. Oxford: Oxford University Press, 1989.

HALLIDAY, M.; MATTHIESSEN, C. An introduction to Functional Grammar. 3. ed. London: Routledge, 2014.

JENKINS, H. Cultura da convergência. 2. ed. São Paulo: Aleph, 2009.

KALANTZIS, M.; COPE, B. Literacies. Cambridge University Press.New York, 2012.

KLEIMAN, A. Agenda de pesquisa e ação em linguística aplicada: problematizações. In: MOITA LOPES, L. P. (Org.) Linguística Aplicada na modernidade recente: festscbrift para Antonieta Celani. São Paulo: Parábola, 2013.

MOITA LOPES, L. P. Uma linguística aplicada mestiça e ideológica: interrogando o campo como linguista aplicado. In: MOITA LOPES, L. P. (Org.) Por uma Linguística Aplicada INdisciplinar. São Paulo: Parábola, 2006. 
ROJO, R. Materiais didáticos no ensino de línguas. In: MOITA LOPES, L. P. (Org.) Linguística Aplicada na modernidade recente: festschrift para Antonieta Celani. São Paulo: Parábola, 2013.

ROJO, R. Pedagogia dos multiletramentos: diversidade cultural e de linguagens na escola. In: ROJO, R; MOURA, E. Multiletramentos na escola. São Paulo: Parábola Editorial, 2012.

ROJO, R. Letramentos múltiplos: escola e inclusão social. São Paulo: Parábola. Editorial, 2009.

SILVA, T.T. A produção social da identidade e da diferença. In: Identidade e diferença: a perspectiva dos estudos culturais. Petrópolis, RJ: Vozes, 2000, p. 73-102.

SOUZA, A. Letramentos de reexistência: poesia, grafite, música, dança. São Paulo: Parábola Editorial, 2011.

THE NEW LONDON GROUP. A pedagogy of multiliteracies: designing social futures. Harvard Educational Review, 66, 1, Spring 1996. p. 60-92.

TILIO, R. Repensando a abordagem comunicativa: multiltramentos em uma abordagem consciente e conscientizadora. In: ROCHA, C. H.; MACIEL, R. (Orgs.) Língua estrangeira e formação cidadã: por entre discursos e práticas. Campinas: Pontes, 2013. p. 51-67.

TILIO, R.; ROCHA, C. As dimensões da linguagem em livro didáticos de inglês para o Ensino Fundamental I. Trabalhos em Linguística Aplicada. v.48, p.295 - 315, 2009.

VOLÓCHINOV, V. Marxismo e filosofia da linguagem: problemas fundamentais do método sociológico na ciência da linguagem. São Paulo: Editora 34, 2017.

Recebido: 14/09/2019

Aceito: 2/11/2019

Publicado: 3/03/2020 